\title{
THE ANTIMONY TREATMENT OF KALA-AZAR
}

\author{
By Sir Leonard Rogers, K.C.S.I., C.I.E., F.R.S.
}

$\mathrm{T}$ HE progress during the last quarter of a century, due to many workers, in the treat. ment of the deadly kala-azar of north-east India and the Mediterranean basin has not attracted the attention it deserves. The epidemic form spread two hundred miles up the Brahmaputra Valley in the last two decades of the nineteenth century, with a case mortality of 96 per cent, and it caused a reduction of 31.5 per cent in the population of the Nowgong district in one decade. In 1890 G. M. Giles incorrectly reported kala-azar to be due to hookworms; in $1897 \mathrm{~L}$. Rogers failed to differentiate the fever from malaria, but established a house or site infection, which enabled Dodds-Price to stamp it out of tea estates. The extension of the epidemic to the east was thus checked for two decades, until the influenza outbreak of 1918 caused kala-azar to break out again in the Sibsagar district.

In 1903 Leishman and Donovan independently discovered the human stage of the causative protozoal parasite (Leishmania donovani), which Ronald Ross called after them when the flagellate stage was discovered by culture by Rogers in 1904. Work in the Calcutta Medical College hospital also proved that the malarial cachexia of Twining (1835) is nothing but a sporadic form of kala-azar. The very similar Leishmania tropica is the cause of oriental sore, and it was the discovery in 1913 by Vianna in Brazil of the effectiveness of tartar emetic intravenously in that infection that led to its successful trial in the Mediterranean in infantile kala-azar in Sicily by Cristina and Caronia reported early in 1915. Rogers immediately reported that he had independently obtained good results with tartar emetic in the India kala-azar after trying other antimony preparations, and in October 1915 both he and Muir published their results. Further trials showed that both sodium. antimony tartrate, and a colloidal solution of antimony sulphide, made by Fisher of the Madras Educational Service, were equally effective and rather less toxic than the potassium salt.

This important discovery came in time to enable McCombie Young to control the Sibsagar outbreak through two to three months' intravenous injections of tartar emetic in 80,000 village cases in Assam by 1921, with a recovery rate of 88 per cent, against 4 per cent in the early Nowgong epidemic. Moreover, the next census showed no fall in the Sibsagar population. Muir also found that systematic treatment of cases in the Kulna hospital led to the disappearance of cases coming from the surrounding villages, and thus kala-azar became an easily controlled disease, given sufficient medical staff, as tartar emetic is very cheap.

It remained for the chemists in India and Europe to seek for even more efficient antimony preparations, and they naturally turned to the less toxic pentavalent ones. The first of these was introduced (and patented) by Dr. U. N. Brah. manchari in Calcutta in 1921, under the name of urea stibamine. This proved less toxic and more effective, and it enabled more than 90 per cent of cases to be cured by intravenous injections within a few days, although so late as 1928, R. N. Chopra, professor of pharmacology in the School of Tropical Medicine, Calcutta, reported this preparation to vary widely in its antimony content and to be uncertain in its composition. In the meantime, von Heyden in Germany prepared a series of pentavalent antimony salts, which were compre. hensively tested by I. E. Napier in the hospital of the Calcutta School of Tropical Medicine. Both von Heyden 471, or stibosan, and 693, neostibosan, proved effective, and the latter proved to be the best, with more than 90 per cent of cures after eight daily intravenous injections. In 1937 a final advance was made by the introduction by Kikuth and Schmidt of solulostibosan, which Struthers and Lin in China, and Yates and Napier in Calcutta, found to be equally effective by the much more convenient intramuscular injections, especially in the young children so frequently attacked by kala-azar.

The value of neostibosan is shown by a systematic treatment of all the kala-azar cases in a group of Bengal villages by Napier, with a reduction from 121 and 127 in the first two years, to 12 and 3 in the fifth and sixth years and later to nil. Further, between 1923 and 1933, the Assam Government treated more than 300,000 cases, and relied largely on urea stibamine, which was adopted as the preferable drug in 1935. Between 1925 and 1936 the treated cases in Assam fell to one sixth and the deaths to one ninth of the former rate.

Unfortunately for such a poor country as India, the more rapid effects of the pentavalent preparations over the original trivalent tartar emetic is offset by a curative course of the former costing 160 times as much as the latter, according to Napier, who in 1925 found a course of stibosan to cost $£ 25$ s. and one of urea stibsmine $£ 3-2$ 
prohibitive sum for poor villagers in India. Napier found the village cases near Calcutta to amount to 33 per thousand population, a rate which would give one million in Bengal. The true number must be much less, as in large areas the prevalence is far less than near Calcutta. Owing to their much more scattered distribution in Bengal than in Assam, and the absence of qualified doctors in Indian villages, the problem of treatment in Bengal is more difficult, and requires for its solution a far cheaper preparation, which is equally effective as the pentavalent antimony ones. With such a drug and sufficient village medical staff, kala-azar could be reduced to small proportions.

\section{O B I T U A R I E S}

\section{Sir William Prout, K.C.M.G., O.B.E.}

$\mathrm{T}$ HE death of Sir William T. Prout occurred on November 18, at his residence at the Manor House, Lingfield, Surrey. He was born in 1862, the son of Mr. William Prout of Mauritius, and was educated in the University of Edinburgh, graduating in medicino in 1884. Ho served as a medical officor in Mauritius until his transfer as an assistant Colonial surgeon under the Colonial Office in the Gold Coast in 1888, serving later in the Gambia until his promotion to the post of principal medical officer in Sierra Leone in 1895, where he was an official member of Legislative Council until his retirement in 1906.

During his service in these territories, Prout acquired valuable knowledge and experience in the treatment of tropical diseases, publishing original papers on yaws ("Liseases of Warm Climates" Davidson); Filaria volvulus (Arch. Parasit., May 1901) ; filariasis in Sierra Leone (Brit. Med.J., 1902), etc. He was actively interested in the preventive aspect of tropical medicine, and in the improvement of conditions of life for both Europeans and natives. It was largely due to his initiative that application of the principles of tropical sanitation became increasingly employed in West Africa and elsewhere, with the corresponding improvement in life and health which has been such a marked feature in the early years of this century.

Following his retirement from West Africa in 1906, Prout became honorary lecturer in tropical medicine in the University of Liverpool. He was appointed medical adviser to the Colonial Office in 1912, and later became consulting physician to the Colonial Office until his retirement in 1929, serving during the War of 1914-18 with the R.A.N1.C. in Egypt, and being twice mentioned in dispatches. He was one of the original members of the Advisory Medical and Sanitary Committeo of the Colonial Office of which he remained a member until his death, and was an ex-president of the Tropical Section of the Royal Society of Medicine, a fellow of the Royal Medical Society, Edinburgh, and a follow of the Royal Society of Tropical Medicine.

The honour of C.M.G. was conferred on him in 1905, that of knighthood in 1924, and K.C.Mr.G. in 1928, while he also received an O.B.E. (military) for his war service.

He married Miss Mary Mackenzie in 1888 and had two children, a son being killed during the War of 1914-18.

\section{Mr. P. H. Grimshaw, I.S.O.}

Percy Hall Grimshaiv found the bent of his life when in 1895 he forsook a clerk's stool in a bank in Leeds to fill a post in the Royal Scottish Museum in Edinburgh. His earlier interests had been botanical, but the chance that, of his colleagues in the Natural History Tepartment, Dr. R. H. Traquair was particularly interested in fossil fishes and Dr. Eagle Clarke in birds and mammals, turned his attention to the lower forms of animal life, and he singled out for investigation the insects and particularly the Diptera. His papers, mostly published in the Annals of Scottish Natural History and its successor the Scottish Naturalist, which for many years he assisted in editing, added greatly to the knowledge of the distribution of insects in Scotland, and he travelled widely on the mainland and in the outer islands to collect material for his "Diptera Scotica" and other contributions.

One of his interesting discoveries was the presence in Great Britain of a bot-fly (Cephenomyia rufibarbis) parasitic on red-deer, and his study of the life-history of the destructivo heather-beetle (Lochmaca suturalis), made in connexion with the Committee of Inquiry on Grouse Disease, suggested the few measures of control which seem to be possible.

When he was appointed keeper of the Natural History Lepartment of the Royal Scottish Museum in 1930, Grimshaw continued the development of the educational appeal of the exhibits, and under his supervision was created a Children's Gallery which for the attractiveness and suggestiveness of its collections would be difficult to beat.

On his retiral from the keepership in 1935 he was decorated with the Imperial Service Order. He died suddenly on November 14, at the age of sixty-nine years.

JaMes Ritchie.

\section{Prof. Anton von Eiselsberg}

Prof. Anton Fremerr von Esselsbera, the eminent Vienna surgeon, who died last October, wăs born at Steinhaus in Upper Austria on July 31, 1860. He received his medical education in Vienna, Wurzburg, Zurich and Paris, and qualified in Vienna in 1884. After serving as assistant to Prof. Billroth, the pioneer in visceral surgery, he was appointed successively professor of surgery at Utrecht (1893), Königsberg (1896) and Vienna (1901), where he retired in 1931. Besides being a first-class operator and a 